\title{
Factors Affecting the Performance of F\&B Industry in Malaysia and Indonesia
}

\author{
Agung Masyad Fawzi ${ }^{1^{*}}$, Sunarti ${ }^{2}$ \\ ${ }^{1,2}$ School of Economic, Finance and Banking, College of Business, Universiti Utara Malaysia, Sintok, Malaysia \\ ${ }^{1}$ mf.agung96@gmail.com, 2sunarti@oyagsb.uum.edu.my *corresponding authors
}

\begin{abstract}
This study investigated the influence of financial ratios on company's performance in Malaysia and Indonesia F\&B industry period 2011 - 2018. The samples generated $37 \mathrm{~F} \& \mathrm{~B}$ companies and 12 F\&B companies listed on Bursa Malaysia and Indonesia Stock Exchange respectively. By using multiple regression analysis for panel data, the study revealed that CR and DER had no influence on ROA, while TAT and NPM had positive effect on ROA. Also, CR and DER had no influence on ROE in Malaysia F\&B industry, but then, these variables had positive effect on ROE in Indonesia F\&B industry. While TAT and NPM had positive effect on ROE. This paper is expected to provide beneficial information to related parties to take better consideration on the actual variables having significant effect on company's ROA and ROE. This paper is also academically expected to be a beneficial reference for further research development.
\end{abstract}

Keywords: F\&B Industry, financial ratios, company’s performance, Indonesia, Malaysia.

\section{Faktor-Faktor yang Mempengaruhi Kinerja Industri Makanan dan Minuman di Malaysia dan Indonesia}

\begin{abstract}
Abstrak
Penelitian ini bertujuan untuk menganalisis pengaruh rasio keuangan terhadap kinerja perusahaan di industri makanan dan minuman di Malaysia dan Indonesia periode 2011 - 2018. Sampel penelitian adalah 37 perusahaan makanan dan minuman yang terdaftar di Bursa Malaysia dan 12 perusahaan makanan dan minuman yang terdaftar di Bursa Efek Indonesia. Hasil penelitian dari analisis regresi berganda untuk data panel menunjukkan bahwa CR dan DER tidak berpengaruh terhadap ROA, TAT dan NPM berpengaruh positif terhadap ROA. CR dan DER tidak berpengaruh terhadap ROE pada industri makanan dan minuman di Malaysia, namun berpengaruh positif terhadap ROE di Indonesia. TAT dan NPM berpengaruh positif terhadap ROE. Makalah ini diharapkan dapat memberikan informasi keuangan yang bermanfaat bagi manajemen perusahaan terkait untuk lebih mempertimbangkan variabel aktual yang berpengaruh signifikan terhadap penilaian ROA dan ROE pada perusahaan. Makalah ini juga diharapkan secara akademis dapat menjadi referensi yang bermanfaat untuk pengembangan penelitian selanjutnya.
\end{abstract}

Kata kunci: industri makanan dan minuman, rasio utang terhadap ekuitas, kinerja perusahaan, Indonesia, Malaysia

\section{INTRODUCTION}

The presence of companies in every industry is basically intended to make profit. Currently in the economy of developing countries, the reliable performance of every company in every business sector in the market is certainly notable. Thus, the financial performance of a company is indeed valuable for the public (investors) which they are able to measure and assess the success of related company from the financial data provided (Linares et al., 2018). One way to analyze the financial data is by conducting financial ratio analysis with the purpose to assess a company's financial condition along with its beneficial use for any 
economic decision-making done by related parties, such as creditors, financial managers, and investors (Delen et al., 2013).

It notices that leverage ratio, liquidity ratio, profitability ratio, and activity ratio are mainly inclusive in financial ratio. In addition, based on Erdogan \& Yamaltdinova (2019), return on equity (ROE) and return on asset (ROA) are generally as a gauge of company's performance, in terms of company's profitability, and are important and meaningful for the investors as good benchmark of their economic decision-making, due to the potential increase of investment benefits the investors will get. Then, as one of sub-sectors in manufacturing industry, the preference of F\&B industry in this study is with regard to its potential and prominent role in country's economic growth and domestic development of industrial sector, particularly in developing countries (Briscoe \& Tripp, 2015).

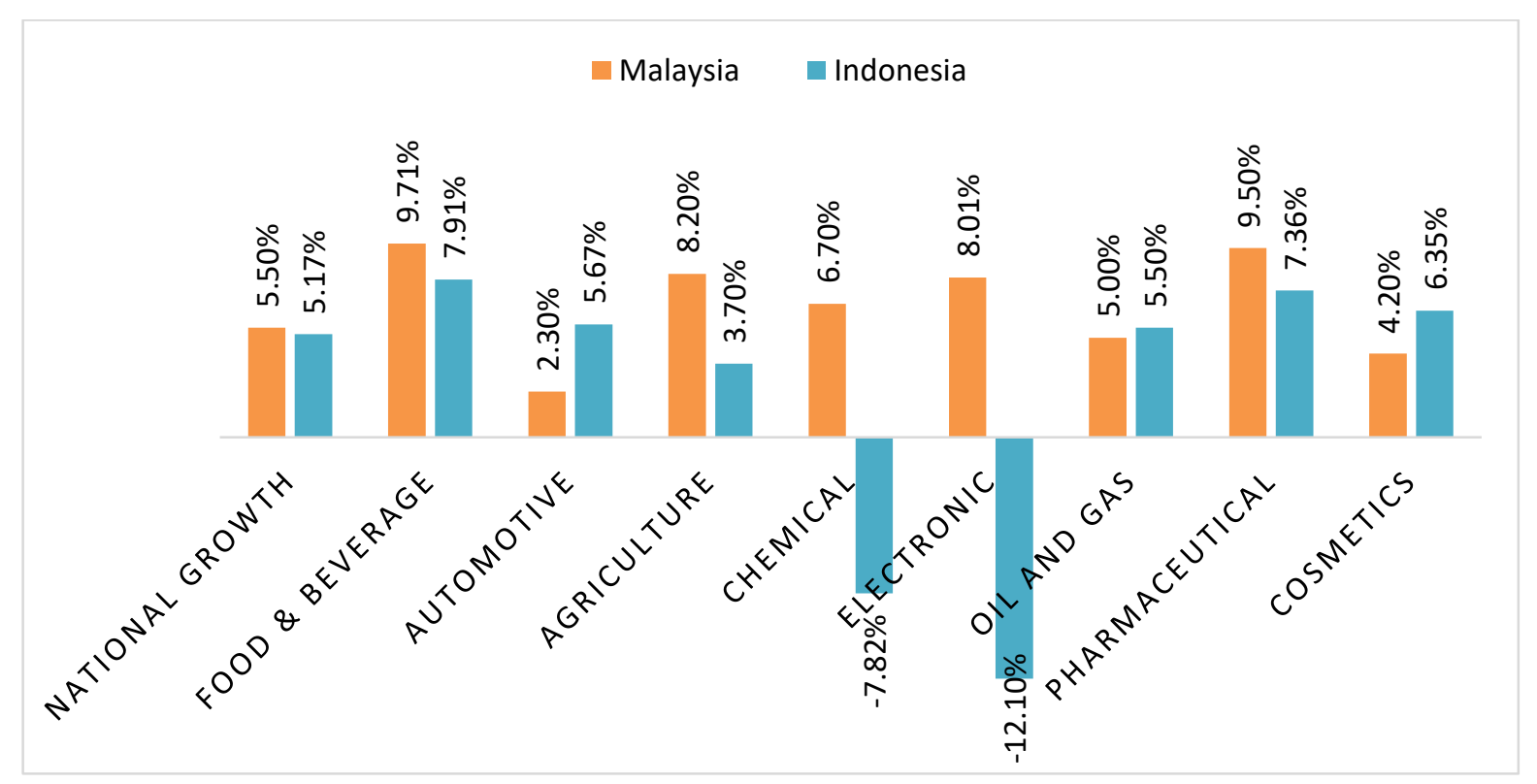

Source: Department of Statistics Malaysia \& Central Bureau of Statistics Indonesia

Figure 1: National and Sectors of Industry Growth in Malaysia \& Indonesia 2018

Based on Figure 1, it has been noticed that in 2018, the growth of F\&B industry both in Malaysia and Indonesia had the highest percentage rate compared with other industries within the country. And also, by considering the national growth of both Malaysia and Indonesia in 2018, the growth of F\&B industry itself was even still higher than the national growth of both countries. Thus, in this research, this is considered as the main points of the selection and chosen of the related industry. Furthermore, in Malaysia, according to Mahidin (2019), by having strong characteristic of its large and potential export market, the industry of Malaysia F\&B has been included in industries with fast-growing performance. It was noticed that in 2017, this industry had recorded its own contribution as much as RM82.8 billion of gross output value in the market. Also, in 2017, the largest value of gross output contribution of $81.1 \%$ was generated from the food services as much as RM67.1 billion. At the same year period, the second place of gross output value contribution of 
$10.7 \%$ was taken by the beverage services as much as RM8.8 billion, while the catering services contributed $8.2 \%$ which was as much as RM6.8 billion (Mahidin, 2019).

While in Indonesia, the Indonesia Minister of Industry, Airlangga Hartarto, stated that the currently main leading of manufacturing sectors along with its potential contribution towards national economic growth in 2018 was the F\&B industry. It was so far assessed through its positive performance achievements reflected on its influence and role of increasing productivity, employment, exports, and investment as well. At the same year, it was noticed that the industry growth of F\&B of $7.91 \%$ had even exceeded $5.17 \%$ of the national economic growth. There was also a supporting contribution of Rp. 56.60 trillion generated from the sector of food industry in 2018 and the total investment value realized in the sector of manufacturing industry had reached Rp.222.3 trillion at the same year period. The Minister of Industry added, Indonesia products of F\&B sector have been known, in the global arena, to have competitiveness through a variety of types. This was marked by the achievement of USD29.91 billion of export value in 2018 (Hartarto, 2019).

Afterwards, according to Pettinger (2017), the company's competence to earn profit is also potentially influenced by changes in the economic conditions of a country, which also affects the increase and decrease on the company's performance, for instance the company's ROE and ROA, in certain period. As the statement of problem in this research, an issue has appeared in certain companies of F\&B industry both listed in Bursa Malaysia and Indonesia Stock Exchange from 2011 to 2018. Due to financial distress of currently generating negative net income (loss) in the financial report reflected by negative ratio of return on equity and return on asset resulted, it will as well negatively affect the companies' financial performance in the market. An internally financial approach is using in this research in order to cope with the undesirable income loss happening in related companies by utilizing and assessing the potential influence of company's liquidity, solvency, efficiency, and profitability performance towards company's currently generated profit whether or not as well as which one having the significant influence, especially on both company's ROA and ROE, in F\&B industry in Malaysia and Indonesia.

Current ratio (CR), as one ratio representing company's liquidity, shows the competence of a company to face well its short-term debts. A higher result of CR means higher level of company's ability in meeting its short-term financial obligation, but then a high result of CR can also possibly show that the company has lack of liquidity management where it has more idle cash, which is eventually able to reduce company's performance to generate profit (Durrah \& Rahman, 2016). Then, debt to equity ratio (DER), as one ratio representing company's solvency, shows how far the owners' capital can cover the company's debts to external party. A higher rate of DER shows higher level of total debt to company's equity which means higher company's dependence to external party that can potentially increase company's risk, but then a high result of DER also means that the company has higher capital to support its performance better to generate profit (Ulzanah \& Murtaqi, 2015). And then, total asset turnover (TAT), as one ratio representing company's efficiency, values how efficient the company is in employing its assets to generate sales. A higher rate of TAT indicates that the company uses its assets more productively and is able 
to increase company's profit by having faster asset turnover over the financial period (Warrad \& Omari, 2015). And also, net profit margin (NPM), as one ratio representing company's profitability, shows potency of a company to obtain profit from its sales performance. A higher result of NPM means better company's management and performance to generate higher profit from the net sales, in which this is also preferable for interested investors considering that the company itself is profitable (Kusmayadi et al., 2018).

As a potential measurement of company's performance, return on asset (ROA) reflects the competence of a company in employing its assets to derive profit, while return on equity (ROE) shows the potentcy of a company in making use of its shareholders' equity to gain profit (Robinson et al., 2009). Based on the previous researches in the same research topic along with the inconsistent results of research generated by using the benchmark of selected companies' financial ratio performance, then in this research paper, it has been chosen that liquidity ratio will be represented by company's current ratio (CR), leverage ratio will be represented by company's debt to equity (DER), activity ratio will be represented by company's total asset turnover (TAT), and profitability ratio will be represented by company's net profit margin (NPM). It is expected that a study that investigates the impact of those financial ratio on company's financial performance to generate profit in food and beverage $(F \& B)$ industry, by using data analysis method of multiple regression analysis, could potentially help resolving the situation.

Furthermore during the period 2011 to 2018, author did not find the relevant studies concerned with the analysis of company's performance in F\&B industry both in Indonesia and Malaysia. The countries were chosen due to their strong bilateral relationship economically of their emerging markets, as well as their F\&B industries that had the highest growth in the country in 2018, as the analysis benchmark in this study (Chan, 2018). However, considering both the research gap and the novelty of research where the previous studies had not done the same, this study included four kinds of the financial ratios of their impacts on both the company's ROA and ROE in F\&B industry both in Indonesia and Malaysia, as well as the comparison result of research between these two countries. According to the stated statement of problem, then the objectives of research is to examine the potential and significant impact of DER, CR, NPM, and TAT on both company's ROE and ROA in Malaysia and Indonesia F\&B industry. The study is expected for the potential investors to identify and assess the performance of F\&B industry both in Malaysia and Indonesia whether or not the related companies have efficiently utilized the use of both their assets and shareholders' equity, as well as this paper is expected to be beneficial reference for the academic use of development of further research related to variables influencing company's profitability.

\section{Literature Review}

According to Brobbey (2017), ROA is a financial ratio measuring capability of a company in generating profits from operationally all company's assets utilization. ROA is utilized to value and evaluate the quality and performance of a company in earning the net profit from 
utilization of all company's assets. Also, ROA can be determined as a financial ratio used to evaluate efficiency of a company in generating income from the economic resources had by the company, as well as it can be defined as the result of a comparison between a company's net income and its total asset (Rostami et al., 2016).

The figure of return of asset can basically provide idea towards investors of how efficient the company is in utilizing its source of assets to be converted into net income. While the financial ratio of ROE measures the capability of a company in generating income from the company's investments of its shareholders' equity, in which it reflects how much the profit a company can earn from every value of the utilization of its shareholders' equity (Brobbey, 2017). ROE is also categorized as a potential measurement for the interested parties, especially for investors, in propose to know the company's efficiency in utilizing its source of fund from shareholders' equity to generate better company's profit (Bunea et al., 2019). It is basically concerned with how much profit a company can generate in comparison with total amount of shareholders' equity invested in the company.

Sarwat et al. (2017) attempted to study whether certain financial ratios may significantly affect ROA as the firm's performance in Pakistan. By using the method of multiple regression analysis, the study found that current ratio had significant and positive influence on company's performance. While reversely Mohanty \& Mehrotra (2018) discovered that current ratio had significant and negative influence on ROA firm's performance in India. However, the study of influence of financial ratios on ROA as firm's performance in Nepal conducted by Bhatt \& Verghese (2018), by using the same analysis method of multiple regression, showed a certain result where current ratio apparently did not have significant influence on ROA. Then, Kirmi (2017) had investigated the impact of factors of capital structure on ROA in Nairobi Securities Exchange, Kenya. By applying the correlation analysis, as well as the regression analysis, the result of study showed that debt ratio had significant and positive influence on company's performance.

Chang et al. (2019) had also assessed the impact of capital structure determinants on ROA in the listed firms categorized of Four Asian Tiger countries (Hong Kong, Singapore, South Korea, and Taiwan) using correlation analysis. They revealed that debt ratio had significant and negative influence on firm's ROA. However, the study conducted by Akenga (2017), focusing on effect of financial ratio on listed firm's performance in Kenya, found that debt ratio did not have significant influence on ROA as the company's performance. And then, Imhanzenobe (2019) furthermore analyzed the impact of company's operational efficiency on listed manufacturing firms' performance in Nigeria. They found that asset turnover had significant and positive influence on company's performance. While the study written by Otekunrin et al. (2018) showed the reversely result that asset turnover apparently did not have significant influence on ROA in listed companies in Nigerian Stock Exchange.

Moreover, Ibrahim (2018) investigated a study concerned with the influence of working capital performance on profitability within the industry of manufacture in Iraq. The study applied the use of method of linear regression analysis and the result showed that CR positively had significant impact on company's ROE. However, the study related to financial factors affecting profitability in listed companies in Bursa Malaysia, written by 
Alarussi \& Alhaderi (2018), discovered that significantly current ratio did not have influence on company's ROE. Kerosi et al. (2018) attempted to conduct a study of influence of capital structure determinants on firm's profitability in Nairobi Securities Exchange, Kenya. By utilizing the method of correlation and multiple regression analysis, the result of study revealed that debt ratio had significant and negative influence on the selected company's profitability. Also, Chavali \& Rosario (2018) conducted a study concerned with the influence of factors of capital structure on profitability in listed non-banking and finance companies in India and instead found that debt ratio had significant and positive influence on ROE as the company's performance. But then, Wikan (2017) discovered that debt ratio apparently had no significant impact on ROE in companies listed in LQ45 Index in Indonesia.

Manjunatha \& Gujjar (2018) attempted to investigate potential financial ratio factors affecting the firm's ROE in India. By applying the use of method of extended DuPont analysis, the study found that both firm's net profit margin and asset turnover had significant and positive influence on ROE as the company's performance. It revealed that potentially the ratio of asset turnover and net profit margin reflected the firm's efficiency and effective cost management respectively in generating and enhancing profit, supported by the proper use and utilization of the related company's shareholders' equity. However, a further research with the latest financial data computation and regression of the independent variables on dependent variable will be potentially required, especially concerned with having further testing on the consistency of significantly influence of company's asset turnover and net profit margin on company's performance to generate profit.

Based on the explanation of independent variables' influence on dependent variables in this research, as well as supported by the evidences from the previous studies, then the research hypothesis can be developed as follows:

Ha1: There is significant influence of current ratio (CR), debt to equity ratio (DER), total asset turnover (TAT), and net profit margin (NPM) on return on asset (ROA) both in Malaysian and Indonesian food and beverage (F\&B) industry.

Ha2: There is significant influence of current ratio (CR), debt to equity ratio (DER), total asset turnover (TAT), and net profit margin (NPM) on return on equity (ROE) both in Malaysian and Indonesian food and beverage (F\&B) industry.

Ha3: There is significant different and similar influence of the chosen financial ratio on return on asset (ROA) between Malaysian and Indonesian food and beverage (F\&B) industry.

Ha4: There is significant different and similar influence of the chosen financial ratio on return on equity (ROE) between Malaysian and Indonesian food and beverage (F\&B) industry.

\section{METHOD}

\section{Data}

The research data is secondary data generated from Bloomberg terminal and annual reports of selected F\&B firms listing in Indonesia Stock Exchange and Bursa Malaysia period 2011 
- 2018. Also, this study is using quantitative data based on its characteristic and appertains in panel data (Hox \& Boeije, 2005). The technique of data collection used in the documents and records by analyzing and assessing the financial data provided (Kabir, 2016). And also, the data sources used is from the Bloomberg terminal and official websites of each chosen F\&B company, in terms of all financial data including the financial ratio, from the financial year of 2011 to 2018. The population is all F\&B companies listed in Bursa Malaysia as many as 40 companies and in Indonesia Stock Exchange as many as 26 companies. And then, the criterion of sample selection is F\&B companies that both have provided annual reports and have been listed in Bursa Malaysia and in Indonesia Stock Exchange period 2011 - 2018 (Majid, 2018).

There were 37 F\&B companies listed on Burse Malaysia generated as the research samples, for instance Three-A Resources Bhd, Ajinomoto Bhd, Apollo Food Bhd, Brahim's Holdings Bhd, Carlsberg Brewery Bhd, CCK Consolidated Bhd, CI Holdings Bhd, China Ouhua Winery Bhd, Cocoaland Bhd, Dutch Lady Milk Bhd, Eka Noodles Bhd, Fraser \& Neave Bhd, Guan Chong Bhd, Green Ocean Bhd, Harrisons Holdings Bhd, HB Global Bhd, Heineken Bhd, Hup Seng Industries Bhd, Hwa Tai Industries Bhd, Impiana Hotels Bhd, Johore Tin Bhd, Kawan Food Bhd, Khee San Bhd, London Biscuits Bhd, Lotus KFM Bhd, Malayan Flour Mills Bhd, MSM Malaysia Bhd, Nestle Bhd, OCB Bhd, Oriental Food Industries Bhd, PPB Group Bhd, Power Root Bhd, Rex Industry Bhd, Saudee Group Bhd, Spritzer Bhd, Xinghe Holdings Bhd, and Yee Lee Bhd. While there were 12 companies in Indonesian F\&B industry generated as the research samples, namely PT. Tiga Pilar Sejahtera Food, PT. Wilmar Cahaya Indonesia, PT. Delta Djakarta, PT. Indofood CBP Sukses Makmur, PT. Indofood Sukses Makmur, PT. Multi Bintang Indonesia, PT. Mayora Indah, PT. Prashida Aneka Niaga, PT. Nippon Indosari Corporindo, PT. Sekar Laut, PT. Siantar Top, and PT. Ultrajaya Milk and Trading Company. Also, the purposive sampling is used as research sampling technique in this research, in which it is included into nonprobability sampling (Daniel, 2014).

\section{Method of Analysis}

This study applies Inferential Analysis to value and evaluate the research sample analysis from the population until the estimation and conclusion-making from the research sample through some research methods, including assumptions test, regression analysis, and hypothesis testing (Blaikie, 2011). The research model of data analysis is concerned with three model approaches which are the Ordinary Least-Square (OLS) model, Fixed Effect Model (FEM), and Random Effect Model (REM), so then, firstly Chow test and Hausman test are purposively used to ensure and decide the most suitable model approach, whether ordinary least-square, fixed effect, or random effect, to be used in the panel multiple regression model (Purba \& Bimantara, 2020). This regression was applied due to the use of more than one predictive variable influencing the dependent variable of which factors give the most impact. Secondly, it proceeds to the classical assumption tests which consist of normality test to value if the research residuals data are normally distributed by assessing the probability of Jarque-Bera in the regression model, multicollinearity test to value if 
correlation among the independent variables has existed by assessing the values of correlation between two variables within the multicollinearity matrix table, autocorrelation test to show similarity degree between values of same variables by assessing the standard value of Durbin-Watson (DW) in the regression model, and heteroscedasticity test to assess if there is an inequality of variance of the residuals for all observations in the linear regression model by assessing the probability value of heteroscedasticity likelihood ratio (Ainiyah et al., 2016). In addition, the research data was not transformed into the Log Natural (LN) with the consideration where it potentially passed the heteroscedasticity test (Yobero, 2016).

And eventually, the utilization of predictive model of multiple regression is due to the involvement of more than one independent or predictor variable in the research towards the dependent variable by assessing the value of t-test for the individually impact of predictor variable on dependent variable, f-test for jointly impact of predictors variables on dependent variable, and as well the coefficient of determination for the contribution level of independent variables in affecting dependent variable in the regression model (Stolzenberg, 2004). The model of multiple regression analysis in this research can be formulated and determined as follow:

$\begin{array}{ll}R O A=\alpha+\beta_{1} C R+\beta_{2} D E R+\beta_{3} T A T+\beta_{4} N P M+e & (\text { Model 1) } \\ R O E=\alpha+\beta_{1} C R+\beta_{2} D E R+\beta_{3} T A T+\beta_{4} N P M+e & \text { (Model 2) }\end{array}$

Where $\alpha$ is the intercept; $\beta_{i}(i=1,2, . ., n)$ is the coefficient of variables; ROA is the return on asset; ROE is the return on equity; CR is the current ratio; DER is the debt to equity ratio; TAT is the total asset turnover; NPM is the net profit margin; and $e$ is the error term.

\section{FINDING AND DISCUSSION}

According to Table 1, based on result of Chow test, the probability of cross-section fixed of ROA and ROE as the dependent variables are less than $5 \%$ in both Malaysia and Indonesia F\&B industry which means that temporarily fixed effect model (FEM) is used as the panel regression model. Then, it should be proceeded to Hausman Test, as the second test, to ensure and decide the most suitable model approach of the panel regression. And based on Hausman Test result on Table 1, the probability of cross-section random of ROA and ROE as the dependent variables are less than $5 \%$ as well which decides that FEM is the most suitable model of panel regression for both Malaysia and Indonesia F\&B companies' data (Purba \& Bimantara, 2020).

Table 1. Result of Chow Test and Hausman Test

\begin{tabular}{cccc}
\hline Country & DV & $\begin{array}{c}\text { Cross-section } \\
\text { Fixed }\end{array}$ & $\begin{array}{c}\text { Cross-section } \\
\text { Random }\end{array}$ \\
\hline \multirow{2}{*}{ Malaysia } & ROA & $10.791^{* *}$ & $20.351^{* *}$ \\
& ROE & $5.050^{* *}$ & $52.979^{* *}$ \\
\hline \multirow{2}{*}{ Indonesia } & ROA & $5.741^{* *}$ & $56.886^{* *}$ \\
& ROE & $11.963^{* *}$ & $82.872^{* *}$ \\
\hline
\end{tabular}

Note: ${ }^{* * *},{ }^{* *},{ }^{*}$ denotes significant at $1 \%, 5 \%$, and $10 \%$ level. 
Table 2 explicates the multicollinearity test for both Malaysia's and Indonesia's F\&B industry data where all values of correlation between two variables are less than 0.8 , then it interprets that there is no issue of multicollinearity in this research (Gujarati, 2004).

Table 2. Matrix Table of Multicollinearity Test

\begin{tabular}{cccccc}
\hline Country & Variables & CR & DER & TAT & NPM \\
\hline \multirow{5}{*}{ Malaysia } & CR & 1 & & & \\
& DER & -0.162 & 1 & & \\
& TAT & -0.175 & 0.168 & 1 & 1 \\
\hline \multirow{5}{*}{ Indonesia } & NPM & -0.145 & -0.145 & 0.149 & \\
& CR & 1 & & & \\
& DER & -0.794 & 1 & 1 & 1 \\
& TAT & -0.239 & 0.254 & -0.418 & \\
\hline
\end{tabular}

Next, regarding the results of classical assumption test on Table 3 and Table 4, in terms of normality test for both Malaysia's and Indonesia's data of the F\&B industry, the probability values are more than $5 \%$ of significance level, then it interprets that all data being used in this research is normally distributed. Then, in terms of autocorrelation test for both country's F\&B industry data, the Durbin-Watson (DW) values are between 1 and 3, so then it is able to interpret that there is no issue of autocorrelation in this research. And then, in terms of heteroscedasticity test, the probability value of heteroscedasticity likelihood ratio for both Malaysia's and Indonesia's F\&B industry data are more than 5\% of significance level in which the null hypothesis will be accepted where all data of research regression model is free from heteroscedasticity problem (Ainiyah, et al., 2016).

Table 3. Result of Analysis for Model 1 (ROA as DV)

\begin{tabular}{ccccc}
\hline & \multicolumn{2}{c}{ Malaysia } & \multicolumn{2}{c}{ Indonesia } \\
& Coefficient & Std. Error & Coefficient & Std. Error \\
\hline C & -0.193 & 0.110 & $-0.573^{* *}$ & 0.104 \\
CR & -0.010 & 0.068 & -0.062 & 0.081 \\
DER & -0.051 & 0.052 & 0.061 & 0.085 \\
TAT & $0.368^{* *}$ & 0.065 & $0.965^{* *}$ & 0.102 \\
NPM & $0.877^{* *}$ & 0.040 & $0.718^{* *}$ & 0.043 \\
\hline R $^{2}$ & 0.830 & 0.933 \\
Adjusted R & 0.803 & 0.919 \\
F-Statistic & $31.144^{* *}$ & $73.769^{* *}$ \\
Jarque-Bera & $4.074(0.130)$ & $1.385(0.501)$ \\
Durbin-Watson & 2.219 & \multicolumn{2}{c}{1.448} \\
Likelihood Ratio & $5.161(0.076)$ & $4.651(0.1193)$ \\
Value & Note: ${ }^{* * *}, * * *$ denotes significant at $1 \%, 5 \%$, and $10 \%$ level.
\end{tabular}

Table 3 explicates the outcome of Model 1 where ROA is determined as DV. This study found that CR and DER had no significant influence on ROA in both Malaysia and Indonesia F\&B industry where this result supports the result of research done by Bhatt \& Verghese (2018) which stated that current ratio had no significant impact on profitability 
and Akenga (2017) which discovered that debt ratio had no significant impact on profitability as well. It indicates that the rate or level of company's CR will only identify the company's liquidity performance of its capability to face and meet its short-term financial obligation well, without any impact on the decrease or increase of company's profitability by utilizing its assets to generate profits (Bhatt \& Verghese, 2018). Also, it notices that related companies utilize most of the debt for other purposes that directly have no significant impact on firm's operational performance or change of profit based on utilizing company's assets, which explains that the change of company's leverage rate will not have significant impact to the increase or decrease of company's profitability (Tailab, 2014).

Then, it is found that TAT had significant and positive influence on ROA in both Malaysia and Indonesia F\&B industry where it supports the result of research done by Imhanzenobe (2019) which stated that asset turnover had significant and positive influence on company's performance. It potentially determines and is indicating that a good asset turnover of a company is efficiently and optimally able to earn more company's income through favorable increase of company's sales volume based on the utilization of the company's assets. It means that the increasing rate of company's activity will also be a significant influence on increasing company's profitability (Dimitrić et al., 2019). And then it also notices that NPM had significant and positive influence as well on ROA in both Malaysia and Indonesia F\&B industry where the increase of company's performance to generate profit from its sales will affect towards the increase of its efficiency in utilizing its assets to generate profit. It determines that there is potential possibility that listed F\&B companies, both in Malaysia and Indonesia, prioritize the performance of their sales and expense management in order to generate more profit from the operational performance in terms of sales conducted in the market. And with the assumption that the company's assets value is unchanged, so then it is certain that the increase of company's operational profit will also lead to the increase of company's profitability (ROA) (Woodruff, 2019). Next, the result of adjusted R-squared value of Malaysia F\&B industry is 0.8034 which interprets that $80.34 \%$ of the change or growth of ROA is influenced by all independent variables, while the adjusted $\mathrm{R}$-squared value of Indonesia F\&B industry is 0.9199 which interprets that $91.99 \%$ of the change or growth of ROA is influenced by all independent variables in this research. The remaining percentage of both Malaysia and Indonesia F\&B industry's adjusted R-squared is affected by other factors that did not appertain in this study.

Table 4 explicates the outcome of Model 2 where ROE is determined as DV. It revealed that CR and DER had no significant influence on ROE in Malaysia F\&B industry where it supports the result of research done by Alarussi \& Alhaderi (2018) which stated that CR had no significant impact on profitability and Wikan (2017) which stated that debt ratio had no significant influence on profitability as well. It indicates that the decrease or increase of company's profitability, by utilizing its shareholders' equity to generate profits, will not be directly affected by the change of rate or level of company's $C R$ where the $C R$ itself will only identify the company's liquidity performance of its capability to face and meet well its short-term financial obligation (Alarussi \& Alhaderi, 2018). Also, it notices that the company's solvency potentially tends to be used for other strategic purposes instead 
of supporting and enhancing towards the increasing company's profitability, in which the company's ROE performance is affected by factors other than DER (Tailab, 2014).

Table 4. Result of Analysis for Model 2 (ROE as DV)

\begin{tabular}{ccccc}
\hline & \multicolumn{2}{c}{ Malaysia } & \multicolumn{2}{c}{ Indonesia } \\
& Coefficient & Std. Error & Coefficient & Std. Error \\
\hline C & $-0.350^{* *}$ & 0.145 & $-0.722^{* *}$ & 0.136 \\
CR & -0.027 & 0.089 & $0.536^{* *}$ & 0.106 \\
DER & -0.056 & 0.069 & $0.466^{* *}$ & 0.110 \\
TAT & $0.147^{* *}$ & 0.085 & $1.018^{* *}$ & 0.133 \\
NPM & $0.685^{* *}$ & 0.052 & $0.551^{* *}$ & 0.056 \\
\hline $\mathrm{R}^{2}$ & 0.721 & 0.885 \\
Adjusted R & 0.676 & 0.863 \\
F-Statistic & $16.447^{* *}$ & $41.053^{* *}$ \\
Jarque-Bera & $2.801(0.246)$ & $0.777(0.678)$ \\
Durbin-Watson & \multicolumn{2}{c}{2.267} & \multicolumn{2}{c}{1.482} \\
Likelihood Ratio & $5.987(0.050)$ & $5.161(0.079)$ \\
Value & \multicolumn{2}{c}{}
\end{tabular}

While it is also found that CR and DER had significant and positive impact on ROE in Indonesia F\&B industry where it supports the result of research done by Ibrahim (2018) which detected that $\mathrm{CR}$ had significant and positive influence on company's performance and Chavali \& Rosario (2018) which found that debt ratio had significant and positive influence on company's performance. It firstly shows how well the company utilizes its current assets as potential investment to increase the company's operational performance in generating more profits (Lina, 2014). And also it explicates that the existence of higher rate of DER shows the creditors' better trust in the company, in which the higher the capital had by the company, then the bigger the opportunity had by the company to utilize its capital in the propose to increase the company's performance in terms of earning higher company's income (Wathen, 2015).

Then, this study also revealed that TAT and NPM had significant and positive influence on ROE in both Malaysia and Indonesia F\&B industry where it supports the result of research done by Manjunatha \& Gujjar (2018) which discovered that both net profit margin and asset turnover had significant and positive impact on company's performance as well. It determines further that favorable asset turnover of the company is efficiently and optimally able to result more company's income through significant increasing volume of company's sales (Dimitrić et al., 2019). It also defines that company's capability in enhancing and optimizing its operational sales performance, in terms of resulting more company's income both in Malaysia and Indonesia F\&B industry, will significantly have impact on increasing company's ROE rate. Next, the result of adjusted R-squared value of Malaysia $\mathrm{F} \& \mathrm{~B}$ industry is 0.6769 which interprets that $67.69 \%$ of the change or growth of ROE is influenced by all independent variables, while the adjusted $\mathrm{R}$-squared value of Indonesia F\&B industry is 0.8635 which interprets that $86.35 \%$ of the change of growth of ROE is influenced by all independent variables in this research. The remaining percentage of both 
Malaysia and Indonesia F\&B industry's adjusted R-squared is influenced by other factors that are not included in this research.

It summarizes that firstly there was not significant influence of either current ratio (CR) or debt to equity ratio (DER) on company's return on asset (ROA) both in Malaysia and Indonesia F\&B industry. Meanwhile, either total asset turnover (TAT) or net profit margin (NPM) had significant and positive influence on company's ROA for both industries. Then, either CR or DER had no significant influence on company's return on equity (ROE) in Malaysian F\&B industry, while these variables instead had positive and significant influence on company's ROE in Indonesian F\&B industry. And eventually for either TAT or NPM, these variables had positive and significant influence on company's ROE both in Malaysian and Indonesian F\&B industry.

Table 5. Summary Table of Influence of IV on DV in F\&B Industry period 2011 - 2018

\begin{tabular}{ccccc}
\hline \multirow{2}{*}{ Variable } & \multicolumn{2}{c}{ ROA } & \multicolumn{2}{c}{ ROE } \\
& Indonesia & Malaysia & Indonesia & Malaysia \\
\hline CR & & & $* *$ & \\
DER & $* *$ & $* *$ & $* *$ & $* *$ \\
TAT & $* *$ & $* *$ & $* *$ & $* *$ \\
NPM & $* *$
\end{tabular}

Note: ${ }^{* *}$ defines significant impact at 5\% level.

\section{CONCLUSION}

It concluded that, both in Malaysia and Indonesia F\&B industry, any changes happened on $\mathrm{CR}$ and DER will not have significant impact towards the change of company's ROA, meanwhile the increase of TAT and NPM will significantly stimulate on the increase of ROA as the company's performance. Also in Malaysia F\&B industry, CR and DER did not have significant impact on ROE as well. But then, in Indonesia F\&B industry, a good performance of CR and DER will be in line with the good performance of company's ROE. While both in Malaysia and Indonesia F\&B industry, the enhancement of TAT and NPM will significantly escalate the result of company's ROE.

Related to the implication of study, the result of this research can be utilized as a motivation for other researchers for future research enhancement, especially concerned with the topic of financial performance and financial distress. For the related company's managers and the management, this research can also be utilized for supporting to conduct improvements and better understanding of company's financial performance along with its potential influencing factors to cope with the financial issue happening in the company. Moreover, this research can also be utilized by the related investors as a supporting consideration potentially of an investment decision-making. Moreover, the result of this research can be utilized as a beneficial reference for other researchers for future research enhancement, especially concerned with the topic of financial performance and financial distress. 
Furthermore, it is then suggested for the company's management and related financial managers to pay more attention and better consideration to the potential financial factors, especially to the company's NPM and TAT, that had significantly affected both company's ROE and ROA growth and changes for a better company's performance in terms of generating profits well, both in Malaysia and Indonesia F\&B industry. And then, it is also recommended to extend the research period to see the consistency of research result based on previous researches. Also, it is suggested to analyze and assess the other potential factors which are not included in this research yet that can potentially affect the company's performance, especially the company's profitability, for the propose of further research development.

\section{REFERENCES}

Ainiyah, N., Deliar, A., \& Virtriana, R. (2016). The Classical Assumption Test to Driving Factors of Land Cover Change in the Development Region of Northern Part of West Java. ISPRS - International Archives of the Photogrammetry, Remote Sensing and Spatial Information Sciences, XLI-B6, 205-210. https://doi.org/10.5194/isprsarchives-XLI-B6205-2016.

Akenga, G. (2017). Effect of Liquidity on Financial Performance of Firms Listed at the Nairobi Securities Exchange, Kenya. International Journal of Science and Research, 6(7), 279-285. https://doi.org/10.21275/ART20175036.

Alarussi, A. S., \& Alhaderi, S. M. (2018). Factors affecting profitability in Malaysia. Journal of Economic Studies, 45(3), 442-458. https://doi.org/10.1108/JES-05-2017-0124.

Bhatt, S., \& Verghese, D. N. (2018). Influence of Liquidity on Profitability: Evidence from Nepalese Banks. International Journal of Multidisciplinary and Current Research, 6(5). https://doi.org/10.14741/ijmcr/v.6.5.13.

Blaikie, N. (2011). Inferential Analysis: From Sample to Population. In Analyzing Quantitative Data (pp. 159-213). SAGE Publications Ltd. https://doi.org/10.4135/9781849208604.n7.

Briscoe, P., \& Tripp, G. (2015). Food and Beverage Services. In M. Westcott (Ed.), Introduction to Tourism and Hospitality in BC (2nd ed.). BCcampus.

Brobbey, C. D. (2017). Financial Management: Ratio Analyses. CreateSpace Independent Publishing Platform. https://www.amazon.com/Financial-Management-ChrysDElijah-Brobbey/dp/1976028787.

Bunea, O.-I., Corbos, R.-A., \& Popescu, R.-I. (2019). Influence of some financial indicators on return on equity ratio in the Romanian energy sector - A competitive approach using a DuPont-based analysis. Energy, 189, 116251. https://doi.org/10.1016/j.energy.2019.116251.

Chan, F. (2018). Malaysia and Indonesia Pledge to Build on Strong Bilateral Ties. The Straits Times. https://www.straitstimes.com/asia/se-asia/malaysia-and-indonesia-pledgeto-build-on-strong-bilateral-ties.

Chang, C.-C., Batmunkh, M.-U., Wong, W.-K., \& Jargalsaikhan, M. (2019). Relationship between Capital Structure and Profitability: Evidence from Four Asian Tigers. SSRN 
Jurnal Economia, 17(1), April 2021, 65-80

Electronic Journal. https://doi.org/10.2139/ssrn.3411977.

Chavali, K., \& Rosario, S. (2018). Relationship between capital structure and profitability: A study of Non Banking Finance Companies in India. Academy of Accounting and Financial Studies Journal.

Daniel, J. (2014). Choosing the Type of Nonprobability Sampling. In Sampling Essentials: Practical Guidelines for Making Sampling Choices (pp. 81-124). SAGE Publications, Inc. https://doi.org/10.4135/9781452272047.n4.

Delen, D., Kuzey, C., \& Uyar, A. (2013). Measuring firm performance using financial ratios: A decision tree approach. Expert Systems with Applications, 40(10), 3970-3983. https://doi.org/10.1016/j.eswa.2013.01.012.

Dimitrić, M., Tomas Žiković, I., \& Arbula Blecich, A. (2019). Profitability determinants of hotel companies in selected Mediterranean countries. Economic Research-Ekonomska Istraživanja, 32(1), 1977-1993. https://doi.org/10.1080/1331677X.2019.1642785.

Durrah, O., Rahman, A. A. A., Jamil, S. A., \& Ghafeer, N. A. (2016). Exploring the relationship between liquidity ratios and indicators of financial performance: An analytical study on food industrial companies listed in Amman Bursa. International Journal of Economics and Financial Issues.

Erdogan, M., \& Yamaltdinova, A. (2019). A Panel Study of the Impact of R\&amp;D on Financial Performance: Evidence from an Emerging Market. Procedia Computer Science, 158, 541-545. https://doi.org/10.1016/j.procs.2019.09.087.

Gujarati, D. N. (2004). Basic Econometrics 4th Edition. In Tata McGraw-Hill.

Hartarto, A. (2019). Food and Beverage Industry Becomes the Leading Sector. https://www.idnfinancials.com/archive/news/22992/Food-and-beverage-industrybecomes-the-leading-sector.

Hox, J. J., \& Boeije, H. R. (2005). Hox, Joop J. Boeije, Hennie R. In Encyclopedia of Social Measurement.

Ibrahim, S. S. (2018). Impact of working capital management on profitability of Industrial sector in Iraq. International Journal of Finance \& Banking Studies (2147-4486), 7(1), 27. https://doi.org/10.20525/ijfbs.v7i1.837.

Imhanzenobe, J. O. (2019). Operational efficiency and financial sustainability of listed manufacturing companies in Nigeria. Journal of Accounting and Taxation, 11(1), 17-31. https://doi.org/10.5897/JAT2018.0329.

Kabir, S. M. S. (2016). Basic guidelines for research: An introductory approach for all disciplines. In Book Zone Publication.

Kerosi, O. D., Mugo, K., \& Kalui, M. (2018). The Relationship between Capital Structure and Profitability of Firms Listed at the Nairobi Securities Exchange. African Development Finance Journal, 2(1), 182-216.

Kirmi, P. (2017). Relationship Between Capital Structure and Profitability, Evidence From Listed Energy and Petroleum Companies Listed in Nairobi Securities Exchange. $\begin{array}{lllll}\text { Journal of Investment and Management, } & 6(5), & 97 .\end{array}$ https://doi.org/10.11648/j.jim.20170605.11. 
Kusmayadi, D., Rahman, R., \& Abdullah, Y. (2018). Analysis of The Effect of Net Profit Margin, Price to Book Value, and Debt to Equity Ratio on Stock Return. International Journal of Recent Scientific Research.

Lina, W. (2014). The Effect of Current Ratio on Jordanian Real Estate Sector's Net Profit Margin. European Journal of Economics, Finance and Administrative Sciences. http://www.eurojournals.com/EJEFAS.htm.

Linares, S., Coenders, G., \& Vives, M. (2018). Financial performance and distress profiles. From classification according to financial ratios to compositional classification. Advances in Accounting, 40, 1-10. https://doi.org/10.1016/j.adiac.2017.10.003.

Mahidin, D. S. (2019). Food and Beverage Services. Department of Statistics Malaysia (DOSM).

https://www.dosm.gov.my/v1/index.php?r=column/cthemeByCat\&cat=456\&bul_i d=MWg5UHNIRXFnN2xlWVdDTmErUDV6QT09\&menu_id=b0pIV1E3RW40V WRTUkZocEhyZ1pLUT09.

Majid, U. (2018). Research Fundamentals: Study Design, Population, and Sample Size. Undergraduate Research in Natural and Clinical Science and Technology (URNCST) Journal, 2(1), 1-7. https://doi.org/10.26685/urncst.16.

Manjunatha, T., \& Gujjar, P. (2018). A Study of Indian Software and Networking Companies using Extended Dupont Model. Journal of Engineering \& Management, 2(1), 53-58.

Mohanty, B., \& Mehrotra, S. (2018). Relationship between Liquidity and Profitability: An Exploratory Study of SMEs in India. Emerging Economy Studies, 4(2), 169-181. https://doi.org/10.1177/2394901518795069.

Otekunrin, A., Nwanji, I., Abiodun, S., Dayo, F., \& Felix, D. (2018). Relationship Between Debt Ratio And Financial Performance of Nigerian Quoted Companies. Journal of Social Sciences and Public Policy.

Pettinger, T. (2017). Factors that Affect the Profitability of Firms. ECONOMICS.

Purba, J. H. V., \& Bimantara, D. (2020). The Influence of Asset Management on Financial Performance, with Panel Data Analysis. Proceedings of the 2nd International Seminar on Business, Economics, Social Science and Technology (ISBEST 2019). https://doi.org/10.2991/aebmr.k.200522.031.

Robinson, T. R., Greuning, H. V., Henry, E., \& Broihahn, M. A. (2009). International Financial Statement Analysis. John Wiley \& Sons, Inc.

Rostami, S., Rostami, Z., \& Kohansal, S. (2016). The Effect of Corporate Governance Components on Return on Assets and Stock Return of Companies Listed in Tehran Stock Exchange. Procedia Economics and Finance, 36, 137-146. https://doi.org/10.1016/S2212-5671(16)30025-9.

Sarwat, S., Iqbal, D., Durrani, B. A., Shaikh, K. H., \& Liaquat, F. (2017). Impact of Working Capital Management on the Profitability of Firms: Case of Pakistan's Cement Sector. Journal of Advanced Management Science, 5(3), 238-244. https://doi.org/10.18178/joams.5.3.238-244.

Stolzenberg, R. M. (2004). Multiple Regression Analysis. SAGE Research Methods. https://doi.org/https://dx.doi.org/10.4135/9781848608184.n8. 
Tailab, M. M. (2014). The Effect of Capital Structure on Profitability of Energy American Firms. In International Journal of Business and Management Invention ISSN.

Ulzanah, A. A., \& Murtaqi, I. (2015). The Impact of Earnings Per Share, Debt To Equity Ratio , and Current Ratio Towards the Profitability of Companies Listed in Lq45 From 2009 To 2013. Journal of Business and Management.

Warrad, L., \& Omari, R. (2015). The Impact of Turnover Ratios on Jordanian Services Sectors' Performance. Journal of Modern Accounting and Auditing, 11(2). https://doi.org/10.17265/1548-6583/2015.02.001.

Wathen, J. (2015). 5 Ways to Improve Return on Equity. The Motley Fool. https://www.fool.com/investing/general/2015/01/21/5-ways-to-improve-returnon-equity.aspx.

Wikan, B. U. (2017). Analysis of Current Ratio Changes Effect, Asset Ratio Debt, Total Asset Turnover, Return On Asset, And Price Earning Ratio In Predictinggrowth Income By Considering Corporate Size In The Company Joined In LQ45 Index Year 2013 -2016. International Journal of Economics, Business and Accounting Research (IJEBAR), 1(01). https://doi.org/10.29040/ijebar.v1i01.253.

Woodruff, J. (2019). Factors That Contribute to the Change in Net Profit Margin. Chron. https://smallbusiness.chron.com/factors-contribute-change-net-profit-margin18456.html.

Yobero, C. (2016). Methods for Detecting and Resolving Heteroskedasticity. Rstudio Pubs Static. https://rstudio-pubsstatic.s3.amazonaws.com/187387_3ca34c107405427db0e0f01252b3fbdb.html. 